\title{
COMPARACIÓN DE LA IMAGEN DEL DESTINO TURÍSTICO: ISLA DE MARGARITA. (VENEZUELA), POR PARTE DE LOS TURISTAS NACIONALES E INTERNACIONALES.
}

\author{
Autor \\ Cristina Elena Marcano Lárez \\ Licenciada en Turismo \\ Magister Scientiarum en Turismo \\ Tesista Doctorado sobre Gestión y desarrollo Sostenible del Turismo \\ Escuela de Hotelería y Turismo \\ Universidad de Oriente. Venezuela. \\ email: crismarla@hotmail.com
}

\section{RESUMEN}

Se plantea la ausencia de una imagen clara y definida del destino turístico Isla de Margarita Venezuela, Por lo que se propone determinar la imagen que poseen los turistas tanto nacionales como internacionales de dicho destino, así como el perfil socio demográfico de estos y se comparan las características resaltantes de dichos mercados. Se concluye que para ambos mercados la Isla tiene una imagen de sol y playa, pero no consideran que es un destino de prestigio en el Caribe, ya que existen otras características como la presencia de basura que influye en esta imagen. Es un estudio exploratorio y su importancia radica en el recogimiento de información para futura investigación en la construcción de un modelo de destino Turístico Reputado.

Palabras Claves: Imagen de Destino, Destino Turístico, 


\title{
COMPARISON OF TOURIST DESTINATION IMAGE: MARGARITA ISLAND, VENEZUELA, ON THE PART OF NATIONAL AND FOREIGN TOURISTS
}

\author{
Autor \\ Cristina Elena Marcano Lárez \\ Licenciada en Turismo \\ Magister Scientiarum en Turismo \\ Tesista Doctorado sobre Gestión y desarrollo Sostenible del Turismo \\ Escuela de Hotelería y Turismo \\ Universidad de Oriente. Venezuela. \\ email: crismarla@hotmail.com
}

\begin{abstract}
The absence of a clear and defined image of Margarita Island, Venezuela, as a tourist destination is stated. Therefore, it is intended to determine the image that both national and foreign tourists have about this destination, as well as the socio-demographic profile of these tourists, and to compare the distinctive characteristics of such markets. It is concluded that, for both markets, the Island has a sun and beach image, however, it is not considered a prestigious destination in the Caribbean, due to other factors, such as garbage that have an impact on its image. This is an exploratory study and its importance lies on the gathering of information for further investigation in the construction of a reputed destination model.
\end{abstract}

Key words: Image of Destination, Tourist Destination. 


\section{Planteamiento del Problema}

Al norte de Venezuela en el Mar Caribe y también perteneciente a este país se encuentra la Isla de Margarita, que desde los años ochenta fue conocida por el mercado internacional a raíz de las políticas de la moneda cambiaria, el cual consistió en la devaluación de la moneda nacional (bolívar) por lo que hizo que la Isla de Margarita se convirtiera en un destino muy económico para el mercado internacional y es en ese momento donde comienzan a llegar los primeros flujos de turistas canadienses. Sin que los margariteños se dieran cuenta estaban con una cantidad de turistas en la isla, para lo cual no estaban preparados, luego comenzaron las construcciones de los hoteles, restaurantes y otros servicios al turismo.

\section{Figura $\mathbf{N}^{\circ} 1$}

Mapa de la Isla de Margarita

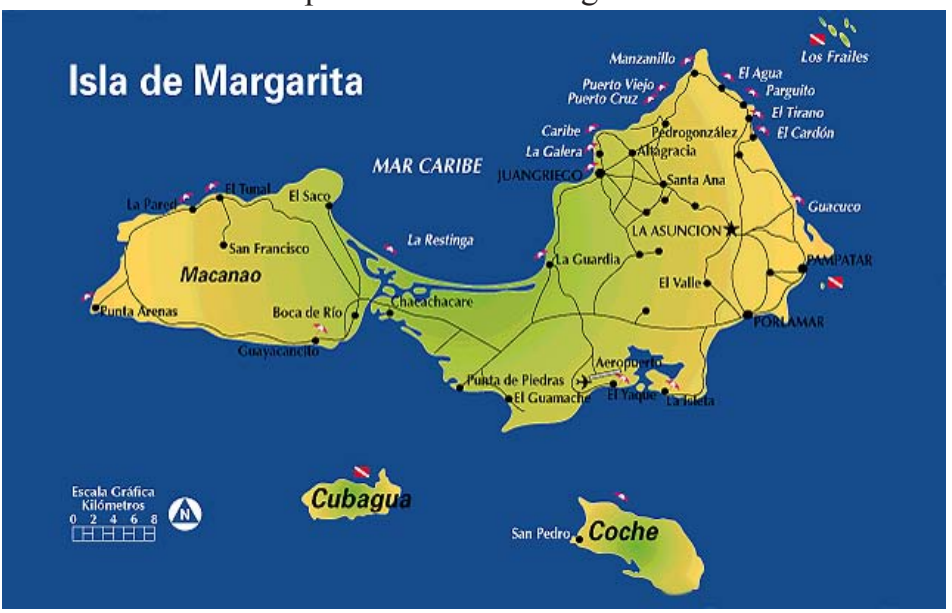

Fuente: Corporación de Turismo del Estado Nueva Esparta

Más tarde la actividad turística se masificó y el país tuvo que planificar sobre la marcha, por lo que todavía se observan muchas debilidades en el desarrollo de la actividad turística. Según el plan de marketing del ente rector del turismo a nivel nacional como lo es el ministerio de turismo nos plantea que el "sistema turístico venezolano presenta algunas preocupantes debilidades, tanto de carácter estructural como coyuntural. Entre las más significativas destacan: 


\section{Carencia de una imagen clara, potente y diferenciada}

El análisis de la encuesta a los turistas demuestra una débil imagen del país bolivariano:

- Falta un posicionamiento claro en la mente del consumidor. La imagen de Venezuela no está identificada con ningún concepto potente: las asociaciones más frecuentemente citadas - "playas" y "clima" - sólo son mencionadas por el $20 \%$ de los entrevistados.

- A pesar de que la mayoría de turistas muestran su satisfacción con su viaje a Venezuela, no saben identificar ningún aspecto que destaque a la hora de definir los atributos con los que están más satisfechos.

- Tampoco existen competidores claramente posicionados en la mente del consumidor: Brasil y México son los más mencionadas, siendo citados por el $17,5 \%$ y el 8,8\% de los entrevistados.

La Isla de Margarita no escapa a esta realidad. A pesar de ser el primer destino turístico que se comenzó a desarrollar en Venezuela, no posee una imagen turística diferenciadora que le permita identificarse en el mundo y posesionarla en los mercados emisores de turismo. Debido a que la actividad turística en la isla ha surgido espontáneamente y no ha sido el producto de actividades planificadas en el tiempo con objetivos específicos, se puede entender que tenga muchas debilidades y la carencia de una imagen de marca como destino es una de ellas. De allí la necesidad de tener una imagen turística que se conozca y se posicione en el mercado de manera que se consolide el destino, como uno de los mejores en el Caribe y ¿por qué no? en el Mundo. Uno de los atractivos más destacados de la Isla de Margarita son sus aguas, que justamente por estar ubicada en el Mar Caribe goza de espectaculares playas e indescriptibles paisajes. Esto se puede observar en el siguiente grafico que presenta la Corporación de Turismo del Estado Nueva Esparta basada en encuestas realizadas en la Semana Santa del año 2008, donde se presentan los sitios más visitados por los turistas, y las playas representan el $42 \%$. 


\section{Figura $\mathrm{N}^{\circ} 2$}

Lugares de la Isla de Margarita, visitados por los turistas Semana Santa 2008

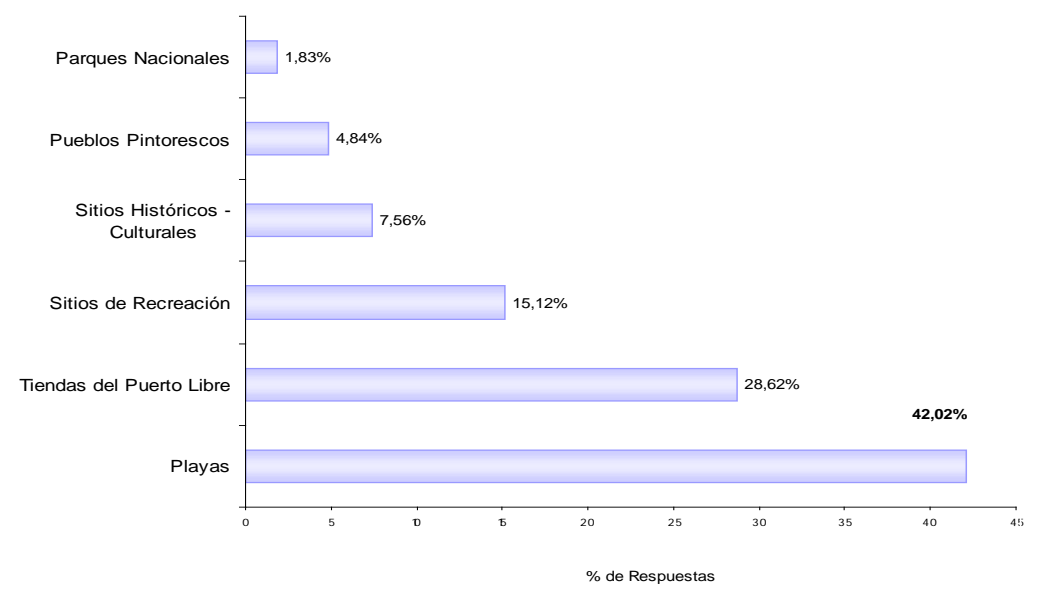

Fuente: Corporación de Turismo del Estado Nueva Esparta

También algunas fortalezas relevantes planteadas en el plan de marketing de Venezuela están basadas, principalmente, en la extraordinaria riqueza, variedad y singularidad de sus recursos y atractivos naturales, que se concentran en un espacio de dimensiones accesibles y confortables. En efecto, la existencia de entornos naturales, paisajísticos y culturales tan diversos como el caribeño, hacen de la Isla de Margarita uno de los destinos con mayores posibilidades para estructurar y ofrecer al mercado experiencias ricas y diversas.

La Isla de Margarita es un destino que dispone de la materia prima necesaria (recursos y atractivos) para satisfacer adecuadamente las motivaciones y necesidades tanto de los segmentos tradicionales como de los nuevos segmentos de demanda turística. Uno de los mercados internacionales más destacado para la Isla de Margarita es Canadá de acuerdo a las estadísticas presentadas por la Corporación de Turismo del estado Nueva Esparta (Corpotur) de acuerdo al siguiente cuadro: 


\section{Cuadro $N^{\circ} 1$}

Total entrada de turistas internacionales por principales paises al estado nueva esparta 2007 - 2008 (enero - junio)

\begin{tabular}{|c|c|c|c|c|}
\hline Posición & País & $\mathbf{N}^{\mathbf{0}}$ turistas 2007 & País & $\mathbf{N}^{\circ}$ turistas 2008 \\
\hline 1 & Canadá & 13.355 & Canadá & 15.103 \\
\hline 2 & Alemania & 11.734 & Alemania & 11.013 \\
\hline 3 & Colombia & 9.375 & Colombia & 6.734 \\
\hline 4 & Gran Bretaña & 5.391 & Trinidad & 5.268 \\
\hline 5 & Trinidad & 4.925 & Gran Bretaña & 4.754 \\
\hline 6 & Holanda & 3.132 & Brasil & 3.591 \\
\hline 7 & Ecuador & 3.065 & Holanda & 3.356 \\
\hline 8 & Dinamarca & 2.238 & Dinamarca & 2.695 \\
\hline 9 & Francia & 1.842 & Suecia & 2.561 \\
\hline 10 & Rep. Checa & 1.695 & Rep. Checa & 2.126 \\
\hline
\end{tabular}

Fuente: Corporación de Turismo del Estado Nueva Esparta

También se observa en esta tabla que además de Canadá se mantienen Alemania y Colombia en los tres primeros lugares en el año 2007 y 2008. Es necesario, sin embargo, convertir esos recursos y atractivos en productos turísticos adecuadamente estructurados para ofrecer experiencias singulares y de alto valor agregado y después, comercializarlos adecuadamente.

En turismo, la gestión estratégica de las marcas puede reportar importantes beneficios estratégicos. Al respecto, las percepciones e imágenes que los visitantes o clientes se forman de un área o zona en concreto tienen un peso significativo sobre la posible viabilidad de la misma como destino turístico. Lo que ellos piensan acerca del medio ambiente natural, del clima y de los residentes de la región, pueden dar forma a las percepciones o imágenes que pueden debilitar o enriquecer el desarrollo exitoso. No obstante, aunque un destino turístico pueda tener una atracción turística de interés y una alta calidad en sus recursos turísticos, una imagen de marca distorsionada puede disminuir las posibilidades de un efectivo posicionamiento.

Entendemos la imagen de un destino como "una construcción de actitudes que consisten en la representación mental del conocimiento de un individuo (creencias), 
sentimientos y la impresión global de un objeto o destino". Baloglu y McCleary (1999). La OMT (1998), define a la imagen de un destino como el "conjunto de ideas o conceptos que se tienen del mismo a nivel individual o colectivo". Según Justo Villafañe, (1999). La primera prioridad de la Imagen "...es su naturaleza intangible. La imagen en el mundo actual es algo muy valioso...una imagen positiva es una de las condiciones para el éxito".

El objetivo principal de este estudio es valorar la Imagen Turística de la Isla de Margarita por parte de los turistas Internacionales y Nacionales para contrastarlos, establecer las diferencias y semejanzas de estos dos mercados y determinar como esta siendo vista como destino turístico, (Imagen Turística). Además de lo anteriormente propuesto, se busca determinar si esa imagen que se tiene de la Isla es lo suficientemente buena como para considerarla como un destino Turístico de imagen positiva para los mercados. Se busca determinar si para los turistas que visitan la Isla de Margarita la consideran como un destino turístico de prestigio, si es reconocida en el Caribe como una Isla de gran valor turístico o si simplemente es un destino más del que no goza de ningún aprecio de los mismos. Esto con el objeto de establecer estrategias que orienten al destino y le ayude a ser reconocido en el mundo, con una imagen clara definida y que identifique al mismo, con sus valores, recursos y elementos diferenciadores, que permita el posesionarse en los clientes como un destino turístico de Calidad. Con este estudio se comienza a dar los primeros pasos en la construcción de un modelo teórico que sirva de orientación para proponer aspectos que debe considerar un destino para que sea de prestigio en el mundo. (Destino Reputado)

\section{Objetivo General}

Analizar la Imagen Turística del Destino Isla de Margarita, (Venezuela) que poseen los turistas Internacionales y los turistas Nacionales con el fin de comparar y establecer diferencias y semejanzas en las características de la misma

\section{Objetivos específicos}

1.- Establecer el perfil demográfico de los Turistas Internacionales que visitan el Destino Turístico Isla de Margarita

2.- Establecer el perfil demográfico de los Turistas Nacionales que visitan el Destino Turístico Isla de Margarita

3.- Determinar la Imagen Turística que tienen los Turistas Internacionales del Destino Isla de Margarita.

4.- Determinar la Imagen Turística que tienen los Turistas Nacionales del Destino Isla de Margarita. 
5.- Comparar la Imagen que tiene los turistas Internacionales de la Isla de Margarita con la Imagen que tienen los Turistas Nacionales

6.- Analizar la Imagen de la Isla de Margarita a través de una matriz DOFA con el fin de aportar estrategias que permitan consolidar una imagen adecuada de la misma

\section{Importancia}

Esta investigación es gran relevancia debido a que ayudará para analizar la imagen Turística de la Isla de Margarita, con el fin de crear una "establecer estrategias que faciliten el reconocimiento mundial del destino turístico y lograr posicionamiento en el mercado que permita competir con otros lugares de características similares y se mantenga en el tiempo la imagen que se quiera proyectar, que no es más que el de un Destino Turístico de prestigio. (Imagen Positiva)

\section{MARCO TEORICO}

\section{Destino Turístico}

Según Rafael Esteve Secall, en artículo publicado en la revista digital www. travelturisme.com. "El destino turístico, como parte de una zona turística, es un ámbito geográfico inferior en tamaño a la zona turística, normalmente de carácter municipal, caracterizado por su especialización en un producto turístico.

Las zonas turísticas han surgido por evolución expansiva de uno o varios destinos turísticos próximos, de uno o varios productos turísticos concretos ofertados en un entorno geográfico, así mismo, próximo; y muchas veces, también, por efecto de la creación de una marca que ha facilitado la creación de una imagen propia y su identificación en el mercado. Dicha evolución es igualmente consecuencia de la tendencia de creación de redes entre empresas, lo que permite ampliar actividades y localizaciones, diversificar motivaciones, en suma, ganar competitividad. Encierta medida, la multiplicidad de productos, segmentos, motivaciones, etc. en el turismo se ha generado como forma para mejorar su competitividad y de combatir uno de los problemas fundamentales que tiene la actividad turística: la estacionalidad." (www.travelturisme.com)

El destino turístico es un producto de base territorial, susceptible de englobar otros productos, que necesariamente debe estar comercializado en los mercados turísticos a través de los operadores del mismo, y que ha de llevar aparejada una marca identificadora. (Sancho: 2001). La definición de Destino Turístico Local propuesta por la 
Organización Mundial del Turismo, OMT dice:

"Un destino turístico local es un lugar físico en el que el visitante pasa al menos una noche. Incluye productos turísticos tales como los servicios de soporte y tracciones, y recursos turísticos que pueden visitarse en desplazamientos de un día. Tiene límites físicos y administrativos que definen su gestión, a si como imágenes y percepciones que definen su competitividad en el mercado. Los destinos turísticos locales incorporan diferentes agentes participantes, entre los cuales suele haber una comunidad local, y pueden dar lugar a destinos de mayor tamaño". Las características que se destacan de esta definición son:

1) Lugar físico o localización donde el visitante pernocta al menos una noche

2) Sirve de soporte del producto turístico local

3) Tiene límites fisicos y administrativos que definen su gestión. Gobierno local, municipio y fuerzas y representantes de la red de recursos, atractivos, actividades y servicios turísticos.

4) Incorporan a los agentes dinámicos de la comunidad local, en esa formulación o entramado.

Los términos Destino Turístico y Municipio Turístico, se refieren a dos conceptos que se usan indistintamente y es necesario definirlos como términos complementarios. Si los Destinos Turísticos tienen un Gobierno Local, éste estaría representado por el Municipio. Si no lo tuviera, se estaría en presencia de un enclave de servicios.

\section{Elementos con que debe contar un destino}

\section{- Turista o Demanda Turística}

Se puede considerar a la demanda turística como el conjunto de servicios solicitado efectivamente por el consumidor. La demanda, como concepto económico, no es más que la disposición a adquirir cantidades determinadas de bienes determinados a precios igualmente determinados. La elección de bienes es considerada, en principio, como un hecho complejo; sólo queda por determinar la calidad, que depende del precio al que es ofrecida o demandada. La demanda refleja solo muy esquemáticamente la situación del mercado en un momento dado. Podríamos también concebirla como el resultado de una cristalización en la que las fuerzas reales que condicionan la consumición de quedan fijadas. La demanda, presentada como complemento de la oferta, ha sido integrada a la fuerza en el esquema racional de la curva del precio. Esa búsqueda permanente de bienestar que tiene el hombre como objetivo de vida tiene en el tiempo libre destinado al turismo y la recreación un valor importante para su desarrollo personal y social. Al 
analizar el comportamiento de la demanda se debe considerar la interrelación entre cuatro variables fundamentales: Necesidades, Deseos, Valores y Beneficios.

El primer impulso que tiene un individuo es una necesidad o privación percibida que se transforma en un deseo al comunicar sus necesidades y que lo lleva de acuerdo a la oferta del mercado a estructurar un producto turístico o recreativo que le permita satisfacer esa necesidad, así el conjunto de personas que se proponen satisfacer sus necesidades de ocio en el mercado se transforma en la demanda turística o recreativa. Consciente o inconscientemente este individuo establece una escala de valores para la selección del destino y prioriza aquel que establezca los mejores beneficios desde la óptica psicológica, funcional y económica. Como concepto primario podemos decir que la demanda compra inicialmente siempre al hacer turismo una "ilusión" con el fin generalmente de evadirse de las rutinas cotidianas y en la búsqueda permanente de un estado de bienestar integral, por lo que en su tiempo libre vacacional dedicado al turismo busca productos y servicios turísticos y recreativos en destinos que le ofrezcan los mejores beneficios y que le permitan obtener el mayor grado de satisfacción durante la totalidad de su viaje.

La motivación de la demanda o sea el conjunto de razones objetivas o subjetivas que conducen a un comportamiento de adhesión a desarrollar una actividad turística o recreativa que produce el desplazamiento de su lugar de residencia habitual es: Conocer, Recrearse y Descansar. Una de estas tres variables es el factor dominante para la elección de un producto y posterior destino, una de las tres actúa como "gatillo" en la toma de decisiones, aunque debemos considerar que es una acción conjunta de las tres con la preponderancia de una de ellas sobre las demás. Paralelamente al definir un viaje busca resolver cuatro preguntas básicas: ¿Como Llego? ¿Donde Duermo? ¿Donde Como? Y la mas difícil de responder ¿Que Hago? ( http://www.turismoaccesible.com. ar). Figuerola (1995) afirma que "la distribución temporal de la demanda, incentivando nuevas épocas de vacaciones y descanso, podrá ser un medio muy eficaz para lograr corregir los desequilibrios provocados por la masificación de las corrientes de turistas en un momento dado y en muy limitados lugares."

\section{- Oferta Turística}

Son todos los bienes y servicios turísticos puestos a la venta para ser consumidos por el turista. Dentro de los elementos de la oferta encontramos la planta turística la cual se divide e equipamiento e instalaciones. El equipamiento turístico son todas aquellas empresas de servicios que sirven, para permitir la estada del visitante en la comunidad receptora. Dentro de esta categoría se encuentran los hoteles, restaurantes, agencias de viajes, empresas de recreación, servicios complementarios etc. Las instalaciones son 
aquellas construcciones que facilitan el disfrute del turista en el destino, como aeropuertos, balnearios, puentes, miradores etc. También dentro de la oferta están los Atractivos Turísticos, que son el principal motivo de viaje, la infraestructura turística, representada por los servicios básicos como luz, agua, aseo y la Superestructura Turística, que no son más que los organismos que regulan y planifican la actividad turística de un destino.

\section{Imagen Turística}

\section{- Imagen de los destinos turísticos}

Los turistas potenciales, suelen tener un conocimiento limitado de los destinos turísticos que no han visitado, la imagen cumple una importante función en la medida de que aquellos destinos con imágenes fuertes, positivas, diferenciadas y reconocibles tienen más posibilidades de ser elegidos por parte de los turistas. Sin embargo, la imagen percibida del destino después de la visita también influye en la satisfacción del turista y en sus intenciones de volver.

Para Baloglu y McCleary (1999), se han llevado a cabo muy pocos estudios al objeto de analizar qué fuerzas influyen en la formación de la imagen de los destinos turísticos entre los individuos. Dada la importancia que tiene la imagen en el proceso de selección de un destino turístico, resulta fundamental comprender cuáles son los factores que influyen en la formación de la imagen inicial y cómo se forma dicha imagen. El conocimiento de todos los factores que influyen en la formación de la imagen ayudará a las instituciones responsables de promocionar los destinos turísticos a proyectar la imagen adecuada a sus mercados objetivos a través de la selección del mix de comunicación más apropiado. La imagen global que puedan tener los individuos de un lugar es el producto de la información que hayan adquirido en el pasado a través de un conjunto de filtros que están relacionados con las fuentes de información y con factores culturales y psicológicos. Estos últimos factores afectan tanto a la perfección como a la cognición, que son dos elementos distintos del proceso de formación de 1a imagen, ya que mientras la percepción se refiere a la aprehensión inmediata de la información del entorno por nuestros sentidos, la cognición hace referencia a la forma en que la información una vez que se recibe es almacenada y organizada en el cerebro.

A pesar de la naturaleza dinámica del proceso de formación de la imagen, muchos autores coinciden en señalar que crear una imagen positiva de un destino o cambiar una imagen negativa es un proceso largo y tedioso, ya que las imágenes tienden considerablemente a ser estables en el tiempo, incluso si se producen mejoras considerables en determinados atributos relevantes de un destino, es muy probable que no se consiga un cambio de imagen de forma rápida. Las campañas publicitarias pueden influir en la mejora de la imagen percibida, ya que los individuos que procedían de regiones en las 
que se habían realizado importantes campañas de comunicación tenían una imagen más positiva. No obstante, el hecho de que los individuos hubieran visitado el destino prueba fue el factor que más influyó en el cambio de Imagen.

La imagen inducida, se fundamenta en fuentes de información comerciales, tales como los folletos y guías de viajes, así como la información proporcionada por los agentes de viaje. Bajo otra terminología, Baloglu, Mccleary (1999) denomina a las imágenes orgánicas e inducidas como informales y formales, respectivamente. Sobre esta base, la imagen orgánica se forma a partir de fuentes de información no directamente relacionadas o asociadas con el lugar turístico, mientras que la imagen inducida es la que emana a partir de los esfuerzos de marketing realizados por los responsables de promocionar el destino turístico. La diferencia fundamental entre ambos tipos de imágenes radica en el control que se tiene en el lugar turístico sobre la imagen que se proyecta. Tanto la imagen orgánica como la imagen inducida hacen referencia a la imagen que se percibe antes de tener una experiencia con el destino turístico. También se conoce como imagen primaria e imagen secundaria

Así mismo, la visita al destino turístico y la experiencia que tengan los individuos en su viaje dará lugar a una imagen más compleja, que igualmente podrá ejercer una influencia en los turistas en la siguiente ocasión que tengan que seleccionar un destino turístico para ir de vacaciones. Basándose en este modelo, dichos autores intentan relacionar el tipo de mensajes más apropiados en la promoción de los destinos turísticos con el tipo de imagen. Así, los mensajes informativos se consideran más efectivos en la etapa de la imagen orgánica, ya que proporcionan un conocimiento del destino a los individuos que no lo han visitado. Los mensajes persuasivos son más apropiados cuando se está conformando la imagen inducida y los mensajes de recuerdo son más convenientes cuando los individuos han conformado una imagen más compleja tras la visita al destino.

La publicidad juega una función importante en el proceso de crear, reforzar y mejorar la imagen de los destinos. Las campañas publicitarias influyen en las percepciones que tienen los individuos sobre los destinos turísticos, así como sobre sus aptitudes hacia los mismos. Dentro de las formas convencionales de publicidad destacan las del medio televisivo por su elevada cobertura, su atractivo emocional y su capacidad de comunicar imágenes visuales. Los folletos son también un importante instrumento que permite reforzar las imágenes existentes a los que se puede tener acceso a través de las agencias de viaje o de los centros de información turística. Con relación a la efectividad de los folletos como fuentes de información existen evidencias empíricas contradictorias.

Si bien los agentes inducidos abiertos presentan una reducida credibilidad, 
contribuyen significativamente a incrementar la notoriedad de los destinos turísticos, debido a su elevada penetración o cobertura. La notoriedad de marca es un elemento relevante en el proceso de decisión de la elección de un destino turístico, ya que constituye la toma de conciencia por parte del individuo de la existencia del lugar. Los tour operadores agentes de viaje cumplen una doble función en el sector turístico: como canales de distribución y con fuentes de información que contribuyen significativamente a crear imágenes entre los clientes. Los agentes de viajes son formadores de opinión de sus clientes y la imagen y conocimiento que tengan los agentes de viajes sobre los destinos turísticos tendrá un impacto significativo en el proceso de toma de decisiones de los viajeros. En este contexto, diferentes autores consideran que los turistas que viajan por primera vez a un destino turístico confían principalmente en las fuentes profesionales (tour operadores y agentes de viaje) en su proceso de búsqueda de información (Baloglu y Mangaloglu, 2001). La experiencia global del turista con un determinado destino estará compuesta por los diferentes encuentros que tenga con múltiples actores y elementos (taxistas, personal del hotel, camareros, museos, teatros, playas, parques temáticos, etc.), que dará lugar al desarrollo de una imagen del destino después de la visita.

\section{- Factores personales que influyen en la formación de la Imagen de los Destinos Turísticos}

Como ya se ha señalado anteriormente, los factores personales o características internas de los turistas afectan también a la imagen percibida. Dichos factores personales hacen referencia, desde la perspectiva del comportamiento del consumidor, a los factores internos, es decir, tanto a las características socio-demográficas de los individuos (sexo, edad, nivel de estudios, ciclo de vida familiar, clase social, residencia, etc.) como a las de naturaleza psicológica (valores, personalidad, estilos de vida, etc.). Dichos factores personales afectan a la organización cognitiva de las percepciones por parte de los individuos, influyendo, por tanto, en las percepciones del entorno y en la imagen resultante. Dentro de los factores internos se incluyen las motivaciones de los turistas, entendidas como beneficios o ventajas que buscan los individuos cuando deciden realizar un viaje, ya que constituyen un factor que influye en el proceso de formación de la imagen y de elección de un destino turístico. La percepción, entendida como el proceso por el cual un individuo selecciona, organiza e interpreta las entradas de información para crear una imagen no sólo depende del estímulo, sino también de estímulos relacionados con el entorno y de las propias características y circunstancias de los individuos que conlleva a que los procesos perceptivos relacionados con la atención, distorsión y retención selectivas difieran de unas personas a otras. (Kotler 2000).

Tal y como señala la publicación Estudios Turísticos $N^{\circ} 45$ (2002), la imagen 
percibida de los destinos varía entre los individuos, ya que en dicha imagen influye cómo perciben los individuos los mensajes que se les comunica y, lógicamente, las personas presentan diferentes sensibilidades a la exposición de la información. Cada individuo percibe de manera diferente idéntica información o estímulos. Esto se debe a que los individuos perciben los estímulos a través de los sentidos, que tienen una capacidad virtualmente idéntica, salvo por causa de deficiencias sensoriales, pero la atención, organización e interpretación de la información captada sensorialmente es completamente personal y subjetiva. En definitiva, la imagen es un concepto subjetivo, que va que depender de la percepción de la persona. Como señala Valls (1992), la comunicación de la imagen de marca no llega nunca virgen al consumidor, ya que la información comunicada se «deforma» a través de los esquemas personales de los individuos. Para (Baloglu y McCleary, 1999) Las fuentes de información constituyen variables de estímulo mientras que las motivaciones y los aspectos sociodemográficas representan características del consumidor Por consiguiente, la imagen general de un destino se forma tanto por las evaluaciones perceptivo / cognitivas como por las afectivas. Esto se observa en el siguiente cuadro:

\section{Figura $\mathbf{N}^{\circ} 3$}

\section{Formación de la Imagen de un Destino}

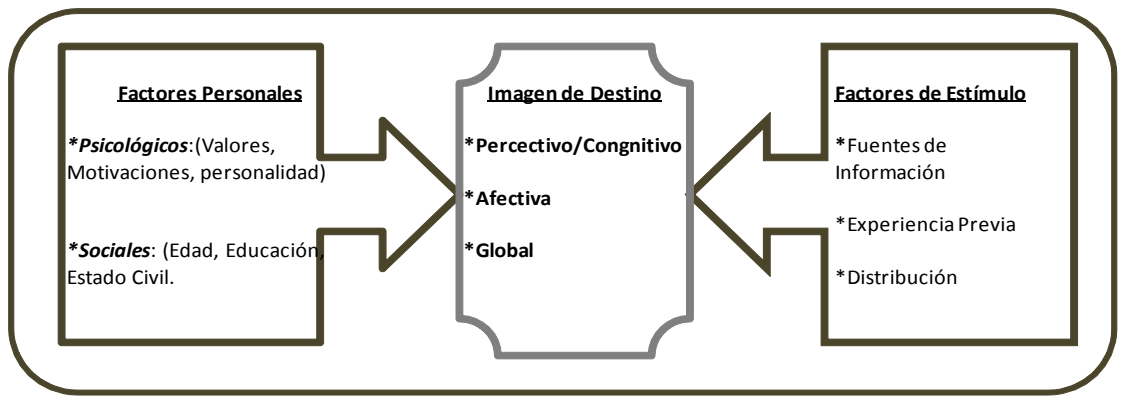

Fuente: Baloglu y McCleary, 1999

\section{METODOLOGÍA}

La presente investigación es de carácter descriptivo, la cual presenta las opiniones de los turistas tanto nacionales como internacionales sobre la imagen de la Isla de Margarita como destino turístico, También es una investigación de campo, por cuanto los datos de los turistas serán recogidos in situ, es decir de forma directa de la realidad. Fue desarrollada geográficamente en la Isla de Margarita, Estado Nueva Esparta, ubicada en el Mar Caribe al norte de Venezuela y perteneciente a este mismo país. Los turistas de ambos mercados fueron fuente primaria, para lo cual se estableció una muestra, que calculada resultó estar compuesta por 150 Turistas, para lo que se hizo 
una afijación proporcional de 75 turistas nacionales y 75 internacionales. En este caso se realizó un muestreo por conglomerado de tipo aleatorio simple. Esto es tomando en consideración porque que la poblaci6n era desconocida. Los sitios de conglomerado fueron: 1.- El Aeropuerto Internacional Santiago Mariño de la Isla de Margarita. 2.- El Terminal Ferrys, 2.-Playa el Agua, 3.-El Centro Comercial Sambil.

Se realizaron entrevistas no estructuradas a los diferentes organismos relacionados con la actividad turística de la Isla de Margarita. Como instrumento para la recolección de datos a los turistas se utilizó un cuestionario tipo encuesta el cual se aplicó tanto a los turistas nacionales como internacionales. El instrumento fue estructurado para que a través de preguntas cerradas el turista tanto nacional como internacional tuviera la oportunidad de dar su opinión sobre la imagen que tiene de la Isla de Margarita como destino turístico del caribe, permitiendo datos cuantitativos. Este instrumento se realizó basado en la operacionalización de las variables. La información contenida en el cuestionario se procesó con el programa de computación Excel. Para el análisis de la información se tomó en cuenta la distribución absoluta y porcentual de los datos, destacando aquellos con más alta frecuencia en el conjunto de valores, es decir la moda (Shao, 1975:190), lo cual dio una idea claramente de su representatividad.

\section{RESULTADOS}

Perfil de los turistas Nacionales e Internacionales que visitan la Isla de Margarita Venezuela.

\section{Cuadro $\mathbf{N}^{\circ} 2$}

Cuadro comparativo del perfil de turistas nacionales v/s internacionales

\begin{tabular}{|c|c|c|c|c|c|c|}
\hline Variable & $\begin{array}{c}\text { Turista } \\
\text { Internacional }\end{array}$ & Característica & $\%$ & $\begin{array}{c}\text { Turista } \\
\text { Nacional }\end{array}$ & Característica & $\%$ \\
\hline Procedencia & País & Argentina & 28 & $\begin{array}{c}\text { Estado de } \\
\text { Venezuela }\end{array}$ & Caracas & 55 \\
\hline Estado civil & Ítems & Casados & 65 & Ítems & Casados & 45 \\
\hline Sexo & Ítems & Masculino & 65 & Ítems & Masculino & 60 \\
\hline Edad & Intervalo & $\begin{array}{c}\text { Entre } 40 \text { a } 60 \\
\text { años }\end{array}$ & 55 & Intervalo & $\begin{array}{c}\text { Entre 20 a } 40 \\
\text { años }\end{array}$ & 55 \\
\hline Ocupación & $\begin{array}{c}\text { Grado de } \\
\text { instrucción }\end{array}$ & Profesional & 85 & $\begin{array}{c}\text { Grado de } \\
\text { Instrucción }\end{array}$ & Profesional & 55 \\
\hline
\end{tabular}

Fuente: Datos Propios

Elaboración: Propia 
En cuanto al perfil de los turistas internacionales y nacionales se observa en este cuadro resumen que la procedencia con el porcentaje más alto fue Argentina con un $28 \%$ y para los turistas nacionales el 55\% proceden de Caracas. Para el estado civil ambos mercados resultaron ser casados con $65 \%$ para los internacionales y $45 \%$ para los nacionales. El sexo fue otro elemento semejante para ambos mercados resultando ser el masculino con mayor porcentaje con $65 \%$ para los turistas internacionales y $60 \%$ para los nacionales. La edad fue un elemento diferenciador, observándose un intervalo entre 40 a 60 años para los turistas internacionales con 55\% y un intervalo entre 20 a 40 años para los nacionales con un porcentaje igual de $55 \%$. Otro elemento semejante fue el grado de instrucción, resultando ser profesionales para ambos mercados, con $85 \%$ para los turistas internacionales y un $55 \%$ para los nacionales.

\section{Imagen de la Isla de Margarita que poseen los Turistas Nacionales e Internacionales}

\section{Cuadro $\mathbf{N}^{\circ} 3$}

Cuadro Comparativo de la Imagen Turística del Destino Isla de Margarita del

Turista Nacional Vs. Internacional

\begin{tabular}{|c|c|c|c|c|c|c|}
\hline Variable & $\begin{array}{c}\text { Turista } \\
\text { Nacional }\end{array}$ & Característica & $\%$ & $\begin{array}{c}\text { Turista } \\
\text { Internacional }\end{array}$ & Característica & $\%$ \\
\hline \multirow{4}{*}{$\begin{array}{l}\text { Servicios } \\
\text { Turísticos }\end{array}$} & Alojamiento & Bueno & 69 & Alojamiento & Bueno & 80 \\
\hline & Restaurantes & Bueno & 67 & Restaurantes & Bueno & 70 \\
\hline & $\begin{array}{l}\text { Transporte } \\
\text { Turístico }\end{array}$ & Malo & 31 & $\begin{array}{l}\text { Transporte } \\
\text { Turístico }\end{array}$ & Bueno & 55 \\
\hline & $\begin{array}{l}\text { Agencias } \\
\text { de viaje y } \\
\text { Mayorista }\end{array}$ & Regular & 35 & $\begin{array}{l}\text { Agencias } \\
\text { de viaje y } \\
\text { Mayorista }\end{array}$ & Bueno & 50 \\
\hline \multirow{3}{*}{$\begin{array}{l}\text { Atractivos } \\
\text { turísticos }\end{array}$} & Playa & Bueno & 80 & Playa & Bueno & 80 \\
\hline & $\begin{array}{l}\text { Parques } \\
\text { temáticos }\end{array}$ & Bueno & 60 & $\begin{array}{l}\text { Parques } \\
\text { temáticos }\end{array}$ & Bueno & 75 \\
\hline & $\begin{array}{c}\text { Centros } \\
\text { comerciales }\end{array}$ & Bueno & 95 & $\begin{array}{c}\text { Centros } \\
\text { comerciales }\end{array}$ & Bueno & 55 \\
\hline
\end{tabular}




\begin{tabular}{|c|c|c|c|c|c|c|}
\hline \multirow{3}{*}{ Personales } & $\begin{array}{l}\text { Su gusto por } \\
\text { el destino } \\
\text { es.... }\end{array}$ & Alto & 85 & $\begin{array}{c}\text { Su gusto por el } \\
\text { destino es.... }\end{array}$ & Alto & 60 \\
\hline & $\begin{array}{c}\text { Sintió deseo } \\
\text { de visitar el } \\
\text { destino... }\end{array}$ & Siempre & 91 & $\begin{array}{c}\text { Sintió deseo } \\
\text { de visitar el } \\
\text { destino... }\end{array}$ & Alguna vez & 80 \\
\hline & $\begin{array}{c}\text { Tuvo } \\
\text { alternativa } \\
\text { para elegir el } \\
\text { destino... }\end{array}$ & Mucha & 40 & $\begin{array}{c}\text { Tuvo } \\
\text { alternativa } \\
\text { para elegir el } \\
\text { destino... }\end{array}$ & Mucha & 60 \\
\hline \multirow{4}{*}{ Identidad } & $\begin{array}{l}\text { La gente de la } \\
\text { Isla es... }\end{array}$ & Muy amable & 60 & $\begin{array}{l}\text { La gente de la } \\
\text { Isla es... }\end{array}$ & Muy amable & 80 \\
\hline & Cultura & $\begin{array}{c}\text { Muy } \\
\text { interesante }\end{array}$ & 65 & Cultura & $\begin{array}{c}\text { Muy } \\
\text { interesante }\end{array}$ & 70 \\
\hline & Gastronomía & $\begin{array}{c}\text { Muy } \\
\text { interesante }\end{array}$ & 71 & Gastronomía & $\begin{array}{c}\text { Muy } \\
\text { interesante }\end{array}$ & 51 \\
\hline & Historia & $\begin{array}{c}\text { Muy } \\
\text { interesante }\end{array}$ & 85 & Historia & $\begin{array}{c}\text { Muy } \\
\text { interesante }\end{array}$ & 75 \\
\hline \multirow{3}{*}{$\begin{array}{l}\text { Información } \\
\text { turística }\end{array}$} & $\begin{array}{l}\text { En el lugar de } \\
\text { origen }\end{array}$ & No tuvo & 75 & $\begin{array}{l}\text { En el lugar de } \\
\text { origen }\end{array}$ & Si tuvo & 75 \\
\hline & En el destino & No tuvo & 60 & En el destino & No tuvo & 60 \\
\hline & Señalización & $\begin{array}{l}\text { Si tuvo }- \text { No } \\
\text { tuvo }\end{array}$ & 51 & Señalización & No contesto & 100 \\
\hline $\begin{array}{c}\text { Medio de } \\
\text { información } \\
\text { que conoció } \\
\text { la Isla }\end{array}$ & Ítems & $\begin{array}{l}\text { Familiares y } \\
\text { amigos }\end{array}$ & 75 & Ítems & Internet & 34 \\
\hline $\begin{array}{l}\text { Imagen } \\
\text { inicial de la } \\
\text { Isla }\end{array}$ & Ítems & Ha mejorado & 70 & Ítems & Ha mejorado & 50 \\
\hline $\begin{array}{l}\text { Imagen en } \\
\text { relación } \\
\text { geográfica }\end{array}$ & Ítems & $\begin{array}{c}\text { Isla de } \\
\text { Venezuela }\end{array}$ & 50 & Ítems & $\begin{array}{l}\text { Isla del } \\
\text { Caribe }\end{array}$ & 59 \\
\hline
\end{tabular}




\begin{tabular}{|c|c|c|c|c|c|c|}
\hline $\begin{array}{c}\text { Elementos } \\
\text { con que } \\
\text { relacional la } \\
\text { Isla }\end{array}$ & Ítems & Sol y playa & 18 & Ítems & Sol y playa & 18 \\
\hline $\begin{array}{c}\text { Aspectos } \\
\text { positivos de } \\
\text { la Isla }\end{array}$ & Ítems & Playas & 31 & Ítems & $\begin{array}{c}\text { Amabilidad } \\
\text { de su gente }\end{array}$ & 31 \\
\hline $\begin{array}{c}\text { Aspectos } \\
\text { negativos de } \\
\text { la Isla }\end{array}$ & Ítems & Basura & 31 & Ítems & $\begin{array}{c}\text { Basura } \\
\text { y poca } \\
\text { información }\end{array}$ & 16 \\
\hline
\end{tabular}

Fuente: Datos encuesta

Elaboración: Propia

Con respecto a los servicios turísticos tanto el alojamiento como los restaurantes son considerados buenos para ambos mercados a diferencia del transporte y las agencias de viajes que los nacionales lo consideraron malo y regular respectivamente y los Internacionales la consideraron bueno. Los atractivos turísticos fueron considerados buenos por ambos mercados. En cuanto a las características personales ambos mercados coincidieron en su alto gusto por el destino y en las muchas alternativas de viaje que tuvieron antes de escoger el destino, una característica diferenciadora fue el deseo de visitar la Isla, pues el nacional siempre sintió el deseo y el internacional alguna vez lo sintió. En cuanto a las características de identidad todas fueron iguales para ambos mercados. Lo relacionado a la información turística el nacional no tuvo en el lugar de origen y el internacional si, ambos mercados no recibieron información en el destino, y en cuanto a la señalización los nacionales igual porcentaje de si y no tuvo información y los internacionales no contestaron. El medio de información que conoció la isla los turistas nacionales lo hicieron por familiares y amigos y los internacionales lo hicieron por internet. Ambos mercados opinaron que la imagen inicial que tenían del destino mejoró con respecto a la imagen en relación geográfica los nacionales ven al destino como una isla de Venezuela y el turista internacional la considera como una Isla del Caribe. Ambos mercados relacionan al destino con sol y playa. En cuanto a los aspectos positivos de la isla los nacionales piensan que son sus playas sin embargo los internacionales opinaron que es la amabilidad de su gente. Y en cuanto a los aspectos negativos los turistas nacionales opinaron que es la basura y los internacionales la basura y la poca información.

- Análisis DOFA del destino Isla de Margarita con respecto a la imagen turística percibida por los turistas nacionales e internacionales que la visitan. 


\section{Visión}

Que la Isla de Margarita sea reconocida en el mundo como un destino turístico de alto prestigio

\section{Misión:}

Promocionar al destino a nivel nacional e internacional utilizando la internet como medio para dar a conocer que la Isla de Margarita cuenta con bellezas naturales, artificiales, manifestaciones culturales, y servicios turísticos de calidad, adecuados para satisfacer las necesidades turísticas, logrando la participación e identificación de las empresas privadas, el sector público y la comunidad.

\section{Fortalezas}

1.-Atractivos naturales de excepcional belleza.

2.-Organismos de turismo, tanto públicos como privados que regulan la actividad..

3.-La Isla cuenta con características resaltantes para ser considerada como un multidestino: playa, sol, montañas, historia, gastronomía, comercio.

4.-Excelente ubicación geográfica.

5.-Cuenta con puertos de cruceros. salida y llegada de barcos todos los lunes.

6.-Régimen preferencial de puerto libre.

7.-Existencia de un ente regulador de precios y control de calidad.

8.-Existencia de un banco de datos turísticos, donde se lleva un registro relativamente actualizado.

9.-Existencia de una planta turística de óptima condiciones.

10.-Geste amable y dispuesta a ofrecer momentos gratos al turista

\section{Debilidades}

1.-Carencia de una visión compartida.

2.-Falta de estrategias para enfrentar la competencia.

3.- Escasa promoción y poco apoyo a los operadores.

4.-Destino poco conocido en los mercados emisores.

5.-Escaso control de calidad.

6.-Débil posicionamiento en los canales de comercialización.

6.- Escaso sistema de transporte interno en la isla.

7.-Inadecuada prestación del servicio turístico, por parte de algunos empleados turísticos, desmotivación del personal contratado.

8.- Poca identificación de la comunidad receptora con la actividad turística.

9.-Falta de liquidez financiera para incentivar planes turísticos.

10.-Incremento de impuestos al turismo.

11.- Presencia de basura en las calles.

12.- Dependencia económica del gobierno nacional. 


\section{Oportunidades}

1-Fortalecimiento de relaciones diplomáticas con países emisores no tradicionales.

2.- Tasa cambiaria favorable al turista internacional.

3.- Acceso aéreo y marítimo con el resto del mundo.

4.- Destino nuevo respecto a competidores.

5.-Aumento de flujos turísticos nuevos.

6.-Percepción de multidestino.

7.-Posibilidades de asociar la imagen turística a valores como cultura, belleza femenina, gastronomía, servicios.

8.- Desarrollo del ecoturismo en el Caribe.

9.-Vuelos charters hacia la Isla de Margarita.

10.- Disposición del Margariteño para atender a los turistas

\section{Amenazas}

1.-Deterioro de la imagen de la isla en el exterior.

2.-Imagen consolidada de otros destinos competitivos y otros destinos con potencialidades similares.

3.-Destinos emergentes en proceso de consolidación de imagen.

4.-Fragilidad en las relaciones diplomáticas con algunos países emisores tradicionales. 5.-Incertidumbre política.

6.-Inestabilidad económica debido al clima de incertidumbre que se vive en el país. 7.-Existencia de un régimen de control cambiario.

8.-Nivel de inseguridad.

9.-Presencia de basura en las calles. 


\section{Cuadro $\mathrm{N}^{\circ} 4$}

Matriz de Impacto DOFA ponderado

\begin{tabular}{|c|c|c|c|c|c|c|c|}
\hline \multirow{2}{*}{ Fortalezas } & \multicolumn{3}{|c|}{ Impacto } & \multirow{2}{*}{ Oportunidades } & \multicolumn{3}{|c|}{ Impacto } \\
\hline & Alto & Medio & Bajo & & Alto & Medio & Bajo \\
\hline $\begin{array}{l}\text { Atractivos naturales de } \\
\text { excepcional belleza }\end{array}$ & $\mathbf{X}$ & & & $\begin{array}{c}\text { Fortalecimiento de } \\
\text { relaciones diplomáticas } \\
\text { con países emisores no } \\
\text { tradicionales. }\end{array}$ & & $\mathbf{X}$ & \\
\hline $\begin{array}{l}\text { Organismos de turismo, } \\
\text { tanto públicos como } \\
\text { privados que regulan la } \\
\text { actividad }\end{array}$ & $\mathbf{X}$ & & & $\begin{array}{l}\text { Tasa cambiaria } \\
\text { favorable al turista } \\
\text { internacional. }\end{array}$ & & $\mathbf{X}$ & \\
\hline $\begin{array}{c}\text { La isla cuenta con } \\
\text { características resaltantes } \\
\text { para ser considerada } \\
\text { como un multidestino: } \\
\text { playa, sol. Montañas, } \\
\text { historia, gastronomía, } \\
\text { comercio }\end{array}$ & $\mathbf{X}$ & & & $\begin{array}{c}\text { Acceso aéreo y } \\
\text { marítimo con el resto } \\
\text { del mundo }\end{array}$ & $\mathbf{X}$ & & \\
\hline $\begin{array}{c}\text { Excelente ubicación } \\
\text { geográfica }\end{array}$ & $\mathbf{X}$ & & & $\begin{array}{c}\text { Destino nuevo respecto } \\
\text { a competidores }\end{array}$ & $\mathbf{X}$ & & \\
\hline $\begin{array}{l}\text { Cuenta con puerto para } \\
\text { cruceros. Llegada y salida } \\
\text { de barcos todos los lunes }\end{array}$ & $\mathbf{X}$ & & & $\begin{array}{l}\text { Aumento de flujos } \\
\text { turísticos nuevos. }\end{array}$ & $\mathbf{X}$ & & \\
\hline $\begin{array}{l}\text { Régimen preferencial de } \\
\text { puerto libre }\end{array}$ & & $\mathbf{X}$ & & $\begin{array}{l}\text { Percepción de } \\
\text { multidestino. }\end{array}$ & $\mathbf{X}$ & & \\
\hline $\begin{array}{l}\text { Existencia de un ente } \\
\text { regulador de precio y } \\
\text { control de calidad }\end{array}$ & & $\mathbf{X}$ & & $\begin{array}{c}\text { Posibilidades de } \\
\text { asociar la imagen } \\
\text { turística a valores } \\
\text { como cultura, belleza } \\
\text { femenina, gastronomía, } \\
\text { servicios. } \\
\end{array}$ & $\mathbf{X}$ & & \\
\hline $\begin{array}{l}\text { Existencia de un banco } \\
\text { de datos turísticos, donde } \\
\text { se lleva un registro } \\
\text { relativamente actualizado }\end{array}$ & & $\mathbf{X}$ & & $\begin{array}{l}\text { Desarrollo del } \\
\text { ecoturismo en el Caribe }\end{array}$ & & $\mathbf{X}$ & \\
\hline $\begin{array}{l}\text { Existencia de una planta } \\
\text { turística de óptima } \\
\text { condiciones }\end{array}$ & $\mathbf{X}$ & & & $\begin{array}{l}\text { Vuelos charters hacia la } \\
\text { Isla de Margarita. }\end{array}$ & $\mathbf{X}$ & & \\
\hline $\begin{array}{c}\text { Geste amable y dispuesta } \\
\text { a ofrecer momentos } \\
\text { gratos al turista }\end{array}$ & $\mathbf{X}$ & & & $\begin{array}{c}\text { Disposición del } \\
\text { Margariteño para } \\
\text { atender a los turistas }\end{array}$ & $X$ & & \\
\hline
\end{tabular}




\begin{tabular}{|c|c|c|c|c|c|c|c|}
\hline \multirow{2}{*}{ Debilidades } & \multicolumn{3}{|c|}{ Impacto } & \multirow{2}{*}{ Amenazas } & \multicolumn{3}{|c|}{ Impacto } \\
\hline & Alto & Medio & Bajo & & Alto & Medio & Bajo \\
\hline $\begin{array}{c}\text { Carencia de una visión } \\
\text { compartida }\end{array}$ & & $\mathrm{X}$ & & $\begin{array}{l}\text { Deterioro de la imagen de } \\
\text { la isla en el exterior. }\end{array}$ & $\mathbf{X}$ & & \\
\hline $\begin{array}{l}\text { Falta de estrategias para } \\
\text { enfrentar la competencia }\end{array}$ & $\mathbf{X}$ & & & $\begin{array}{c}\text { Imagen consolidada de } \\
\text { otros destinos competitivos } \\
\text { y otros destinos con } \\
\text { potencialidades similares. }\end{array}$ & $\mathbf{X}$ & & \\
\hline $\begin{array}{l}\text { Escasa promoción y poco } \\
\text { apoyo a los operadores. }\end{array}$ & $\mathbf{X}$ & & & $\begin{array}{c}\text { Destinos emergentes en } \\
\text { proceso de consolidación } \\
\text { de imagen. }\end{array}$ & $\mathbf{X}$ & & \\
\hline $\begin{array}{l}\text { Destino poco conocido en } \\
\text { los mercados emisores. }\end{array}$ & $\mathbf{X}$ & & & $\begin{array}{l}\text { Fragilidad en las } \\
\text { relaciones diplomáticas con } \\
\text { algunos países emisores } \\
\text { tradicionales. }\end{array}$ & & $\mathbf{X}$ & \\
\hline Escaso control de calidad & $\mathbf{X}$ & & & Incertidumbre política. & $\mathbf{X}$ & & \\
\hline $\begin{array}{l}\text { Débil posicionamiento } \\
\text { en los canales de } \\
\text { comercialización. }\end{array}$ & $\mathbf{X}$ & & & $\begin{array}{l}\text { Inestabilidad económica } \\
\text { debido al clima de } \\
\text { incertidumbre que se vive } \\
\text { en el país. }\end{array}$ & $\mathbf{X}$ & & \\
\hline $\begin{array}{c}\text { Escaso sistema de } \\
\text { transporte interno en la isla. }\end{array}$ & $\mathbf{X}$ & & & $\begin{array}{l}\text { Existencia de un régimen } \\
\text { de control cambiario. }\end{array}$ & $\mathbf{X}$ & & \\
\hline $\begin{array}{l}\text { Inadecuada prestación del } \\
\text { servicio turístico, por parte } \\
\text { de algunos empleados } \\
\text { turísticos. Desmotivación } \\
\text { del personal contratado. }\end{array}$ & $\mathbf{X}$ & & & Nivel de inseguridad & $\mathbf{X}$ & & \\
\hline $\begin{array}{l}\text { Poca identificación de la } \\
\text { comunidad receptora con la } \\
\text { actividad turística. }\end{array}$ & $\mathbf{X}$ & & & $\begin{array}{c}\text { Presencia de basura en las } \\
\text { calles }\end{array}$ & & & \\
\hline $\begin{array}{c}\text { Falta de liquidez financiera } \\
\text { para incentivar planes } \\
\text { turísticos. }\end{array}$ & & $\mathbf{X}$ & & & & & \\
\hline $\begin{array}{c}\text { Incremento de impuestos al } \\
\text { turismo. }\end{array}$ & & & $\mathbf{X}$ & & & & \\
\hline
\end{tabular}

La matriz DOFA ponderada permitió establecer el impacto (Alto, Medio, Bajo ) de cada uno de los elementos de la misma, es decir de los elementos internos del 
destino: Fortalezas, Debilidades, como de los externos: Oportunidades y Amenazas. De esta manera se establecieron estrategias FO; DO; FA; DA tendientes a satisfacer estos elementos. A continuación se observan dichas estrategias:

\section{Cuadro $\mathbf{N}^{\circ} 5$}

Matriz Dofa con estrategias FO; DO; FA; DA

\begin{tabular}{|c|c|c|}
\hline & Fortalezas & Debilidades \\
\hline $\begin{array}{c}\text { Visión } \\
\text { Que la Isla Margarita } \\
\text { sea reconocida en el } \\
\text { mundo como un destino } \\
\text { turístico reputado (Alto } \\
\text { prestigio) } \\
\text { Misión } \\
\text { Promocionar al destino } \\
\text { a nivel nacional e } \\
\text { internacional utilizando } \\
\text { internet como medio } \\
\text { para dar a conocer } \\
\text { que la Isla Margarita } \\
\text { cuenta con bellezas } \\
\text { naturales, artificiales, } \\
\text { manifestaciones } \\
\text { culturales y servicios } \\
\text { turísticos de } \\
\text { calidad adecuados } \\
\text { para satisfacer las } \\
\text { necesidades turísticas, } \\
\text { logrando la participación } \\
\text { e identificación de las } \\
\text { empresas privadas, } \\
\text { el sector publico y la } \\
\text { comunidad }\end{array}$ &  & $\begin{array}{l}\text { 1- Falta de estrategias para } \\
\text { enfrentar la competencia. } \\
\text { 2- Escasa promoción y poco } \\
\text { apoyo a los operadores. } \\
\text { 3- Destino poco conocido en } \\
\text { los mercados emisores. } \\
\text { 4- Escaso control de calidad. } \\
\text { 5- Débil posicionamiento } \\
\text { en los canales de } \\
\text { comercialización. } \\
\text { 6- Escaso sistema de transporte } \\
\text { interno en la isla. } \\
\text { 7- Inadecuada prestación del } \\
\text { servicio turístico, por parte } \\
\text { de algunos empleados } \\
\text { turísticos. Desmotivación } \\
\text { del personal contratado. } \\
\text { 8- Poca identificación de la } \\
\text { comunidad receptora con la } \\
\text { actividad turística. } \\
\text { 9- Falta de liquidez financiera } \\
\text { para incentivar planes } \\
\text { turísticos. }\end{array}$ \\
\hline
\end{tabular}




\begin{tabular}{|c|c|c|}
\hline Oportunidades & Estrategia FO & Estrategia DO \\
\hline 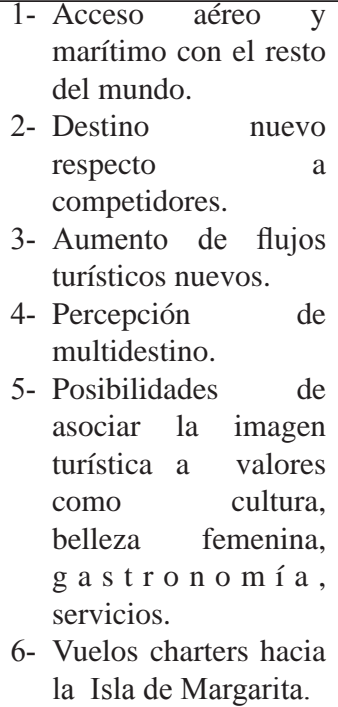 & $\begin{array}{l}\text { 1- Administrar y conservar los } \\
\text { atractivos naturales de la isla } \\
\text { para perduren en el tiempo } \\
\text { 2- Estimular el sector privado } \\
\text { para la conservación y } \\
\text { mantenimiento de la planta } \\
\text { turística } \\
\text { 3- Diseñar un Plan de Promoción } \\
\text { destinado a los turistas } \\
\text { nacionales e internacionales } \\
\text { proyectando la imagen de } \\
\text { multidestino (elemento } \\
\text { diferenciador con respecto a } \\
\text { otros destinos del caribe) con } \\
\text { el fin de convertir a la isla en } \\
\text { un destino preferido del caribe }\end{array}$ & $\begin{array}{l}\text { 1- Establecer r convenio } \\
\text { con líneas aéreas } \\
\text { internacionales para } \\
\text { ofrecer vuelos hacia la Isla } \\
\text { Margarita } \\
\text { 2- Establecer alianzas } \\
\text { estratégicas con tour } \\
\text { operadoresinternacionales } \\
\text { y con operadores de } \\
\text { turismo local } \\
\text { 3- Planificar y realizar ferias } \\
\text { turísticas internacionales } \\
\text { con el fin de dar a conocer } \\
\text { la isla en los diferentes } \\
\text { mercadosycomercializarla } \\
\text { como multidestino }\end{array}$ \\
\hline
\end{tabular}

continua... 


\begin{tabular}{|c|c|c|}
\hline Amenazas & Estrategia FA & Estrategia DA \\
\hline $\begin{array}{l}\text { 1- Deterioro de la } \\
\text { imagen de la isla en el } \\
\text { exterior. } \\
\text { 2- Imagen consolidada } \\
\text { de otros destinos } \\
\text { competitivos y } \\
\text { otros destinos con } \\
\text { p ot en c i a li d a d e s } \\
\text { similares. } \\
\text { 3- Destinos emergentes } \\
\text { en proceso de } \\
\text { consolidación de } \\
\text { imagen. } \\
\text { 4- I n c e r t i d u m b r e } \\
\text { política. } \\
\text { 5- I n e s t a b i } 1 \text { i d a d } \\
\text { económica debido } \\
\text { al clima de } \\
\text { incertidumbre que se } \\
\text { vive en el país. } \\
\text { 6- Nivel de inseguridad. } \\
\text { 7- Presencia de basura } \\
\text { en las calles. }\end{array}$ & $\begin{array}{l}\text { 1- Estimular a los cuerpos } \\
\text { policiales para vigilar } \\
\text { y patrullar los sitios } \\
\text { turísticos de la isla } \\
\text { 2- Estimular a la empresa } \\
\text { Sabempe (encargada } \\
\text { de recoger la basura } \\
\text { en la isla) para recoger } \\
\text { dos veces al dia los } \\
\text { desperdicios generados } \\
\text { en época de temporada } \\
\text { alta }\end{array}$ & $\begin{array}{l}\text { 1- Sensibilizar y capacitar a la } \\
\text { comunidad receptora para el } \\
\text { servicio turístico de calidad } \\
\text { 2- Evaluar periódicamente la } \\
\text { imagen percibida por los turistas } \\
\text { que visitan la Isla Margarita con } \\
\text { el fin de orientar la oferta hacia } \\
\text { la demanda }\end{array}$ \\
\hline
\end{tabular}

De acuerdo a este análisis se proponen las siguientes Estrategias de Acción: 


\section{Cuadro $\mathrm{N}^{\circ} 6$}

Estrategias de Acción

\begin{tabular}{|c|c|c|c|}
\hline Estrategia FO & Actividades & Responsables & Tiempos \\
\hline \multirow{5}{*}{$\begin{array}{l}\text { Administrar } \\
\text { y conservar } \\
\text { los atractivos } \\
\text { naturales de } \\
\text { la isla para } \\
\text { perduren en el } \\
\text { tiempo }\end{array}$} & $\begin{array}{l}\text { - Inventariar el estados } \\
\text { físico de los atractivos } \\
\text { naturales del municipio }\end{array}$ & $\begin{array}{l}\text { - } \quad \text { Dirección de turismo del } \\
\text { Estado de nueva Esparta } \\
\text { - Alcaldía municipales }\end{array}$ & $\begin{array}{l}\text { Enero y julio de } \\
\text { cada año }\end{array}$ \\
\hline & $\begin{array}{l}\text { - Colocar papeleras para } \\
\text { la recolección de basura } \\
\text { en los atractivos }\end{array}$ & $\begin{array}{l}\text { - Gobernación del estado } \\
\text { - } \text { Fondo mixto } \\
\text { - Dirección de turismo } \\
\text { del Estado de Nueva } \\
\text { Esparta } \\
\text { - Alcaldías municipales }\end{array}$ & $\begin{array}{l}\text { Enero de cada } \\
\text { año }\end{array}$ \\
\hline & $\begin{array}{l}\text { - Distribuir minibolsas de } \\
\text { basura para los vehículos } \\
\text { en las entradas de los } \\
\text { atractivos naturales }\end{array}$ & - Alcaldías municipales & 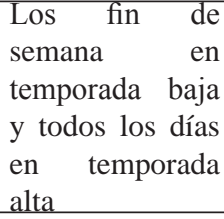 \\
\hline & $\begin{array}{l}\text { - Colocar vallas que } \\
\text { estimulen el turista a } \\
\text { conservar el atractivo }\end{array}$ & 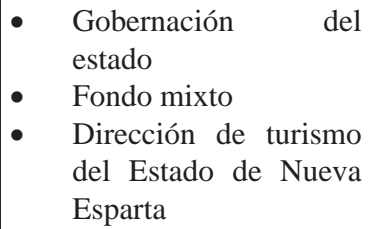 & Una vez al año \\
\hline & $\begin{array}{l}\text { - Fiscalizar para } \\
\text { corroborar el estado de } \\
\text { los atractivos naturales }\end{array}$ & $\begin{array}{l}\text { - Dirección de turismo } \\
\text { del Estado de Nueva } \\
\text { Esparta }\end{array}$ & Dos veces al año \\
\hline \multirow{2}{*}{$\begin{array}{c}\text { Estimular } \\
\text { el sector } \\
\text { privado para la } \\
\text { conservación y } \\
\text { mantenimiento } \\
\text { de la planta } \\
\text { turística }\end{array}$} & $\begin{array}{l}\text { - Realizar reuniones } \\
\text { con los prestadores de } \\
\text { servicios turísticos para } \\
\text { que evalúen y mantengan } \\
\text { en buen estado sus } \\
\text { instalaciones }\end{array}$ & $\begin{array}{l}\text { - } \quad \text { Fondo mixto } \\
\text { Dirección de turismo } \\
\text { del Estado de Nueva } \\
\text { Esparta } \\
\text { - } \\
\text { Prestadores de servicio }\end{array}$ & Dos veces al año \\
\hline & $\begin{array}{l}\text { - Realizar una encuesta } \\
\text { a los componentes de } \\
\text { la planta turística con } \\
\text { el fin de premiar al } \\
\text { establecimiento que } \\
\text { resulte mas favorecido }\end{array}$ & $\begin{array}{l}\text { - } \quad \text { Fondo mixto } \\
\text { Dirección de turismo } \\
\text { del Estado de Nueva } \\
\text { Esparta }\end{array}$ & Una vez al año \\
\hline
\end{tabular}




\begin{tabular}{|c|c|c|c|}
\hline \multirow{6}{*}{$\begin{array}{c}\text { Diseñar } \\
\text { un Plan de } \\
\text { Promoción } \\
\text { destinado a } \\
\text { los turistas } \\
\text { nacionales e } \\
\text { internacionales } \\
\text { proyectando } \\
\text { la imagen de } \\
\text { multidestino } \\
\text { (elemento } \\
\text { diferenciador } \\
\text { con respecto a } \\
\text { otros destinos } \\
\text { del caribe) } \\
\text { con el fin } \\
\text { de convertir } \\
\text { a la isla en } \\
\text { un destino } \\
\text { preferido del } \\
\text { caribe }\end{array}$} & $\begin{array}{l}\text { - Realizar y distribuir } \\
\text { folletos promocionales } \\
\text { dirigida a proyectar la } \\
\text { imagen de la isla como } \\
\text { multidestino }\end{array}$ & $\begin{array}{l}\text { - Fondo mixto } \\
\text { - Dirección de turismo } \\
\text { del Estado de Nueva } \\
\text { Esparta } \\
\text { - Universidad de Oriente }\end{array}$ & Dos veces al año \\
\hline & $\begin{array}{l}\text { - Emprender campañas } \\
\text { publicitarias para estimular } \\
\text { el desplazamiento de } \\
\text { turistas nacionales hacia } \\
\text { la isla }\end{array}$ & $\begin{array}{l}\text { - Fondo mixto } \\
\text { - Dirección de turismo } \\
\text { del Estado de Nueva } \\
\text { Esparta } \\
\text { - Universidad de Oriente }\end{array}$ & $\begin{array}{ll}\text { Una vez al año } \\
\text { durante } & \text { tres } \\
\text { meses } & \end{array}$ \\
\hline & $\begin{array}{l}\text { - Publicar información del } \\
\text { destino Isla Margarita en } \\
\text { revistas especializadas de } \\
\text { turismo }\end{array}$ & $\begin{array}{l}\text { - Dirección de turismo } \\
\text { del Estado de Nueva } \\
\text { Esparta }\end{array}$ & Trimestralmente \\
\hline & $\begin{array}{ll}\text { - } & \text { Realizar } \\
& \text { promocionales del destino }\end{array}$ & $\begin{array}{l}\text { - Dirección de turismo } \\
\text { del Estado de Nueva } \\
\text { Esparta } \\
\text { - Operadores turísticos } \\
\text { - Empresas de servicios } \\
\text { turísticos }\end{array}$ & Trimestralmente \\
\hline & $\begin{array}{l}\text { - Distribuir material } \\
\text { publicitario, folletos, } \\
\text { mapas,hotelesrestaurantes, } \\
\text { entretenimientos etc. de } \\
\text { la Isla Margarita en als } \\
\text { embajadas y consulados de } \\
\text { los principales mercados } \\
\text { emisores de turismo a } \\
\text { nivel mundial }\end{array}$ & $\begin{array}{l}\text { - Fondo mixto } \\
\text { - Dirección de turismo } \\
\text { del Estado de Nueva } \\
\text { Esparta } \\
\text { - Prestadores de servicio } \\
\text { - Operadores turísticos }\end{array}$ & Trimestralmente \\
\hline & $\begin{array}{l}\text { - Actualizar la pagina web de } \\
\text { la corporación de turismo } \\
\text { del Estado de Nueva } \\
\text { Esparta con información } \\
\text { sobre ofertas, servicios y } \\
\text { toda información nueva de } \\
\text { la isla }\end{array}$ & $\begin{array}{l}\text { - Dirección de turismo } \\
\text { del Estado de Nueva } \\
\text { Esparta }\end{array}$ & Semanalmente \\
\hline
\end{tabular}




\begin{tabular}{|c|c|c|c|}
\hline Estrategia DO & Actividades & Responsables & Tiempos \\
\hline \multirow{3}{*}{$\begin{array}{l}\text { E s t a b l e c e r } \\
\text { convenio con } \\
\text { líneas aéreas } \\
\text { internacionales } \\
\text { para ofrecer } \\
\text { vuelos hacia la } \\
\text { Isla Margarita }\end{array}$} & $\begin{array}{l}\text { - Establecimiento de } \\
\text { política de cielos } \\
\text { abiertos }\end{array}$ & $\begin{array}{l}\text { - Gobierno nacional } \\
\text { - Gobernación del Estado de } \\
\text { nueva Esparta } \\
\text { - Dirección de turismo del } \\
\text { Estado de nueva Esparta }\end{array}$ & $\begin{array}{l}\text { Renovable en el } \\
\text { tiempo }\end{array}$ \\
\hline & \begin{tabular}{lr}
\multicolumn{2}{c}{ Exoneración de } \\
impuestos para \\
las líneas aéreas \\
internacionales
\end{tabular} & $\begin{array}{l}\text { - Gobierno nacional } \\
\text { - Gobernación del Estado de } \\
\text { nueva Esparta } \\
\text { - } \text { Dirección de turismo del } \\
\text { Estado de nueva Esparta } \\
\text { - Líneas aéreas involucradas } \\
\end{array}$ & Dos años \\
\hline & $\begin{array}{l}\text { - Exonerar de pago de } \\
\text { alojamiento y comida } \\
\text { para la tripulación } \\
\text { de los vuelos } \\
\text { internacionales que } \\
\text { hagan parada en el } \\
\text { destino Isla Margarita }\end{array}$ & $\begin{array}{l}\text { - Dirección de turismo del } \\
\text { Estado de Nueva Esparta } \\
\text { - } \text { Prestadores de servicios } \\
\text { turísticos de la isla (hoteles, } \\
\text { restaurantes, centros } \\
\text { comerciales, etc.) } \\
\text { - Operadores turísticos }\end{array}$ & Dos años \\
\hline \multirow{2}{*}{$\begin{array}{l}\text { E s t a b l e c e r } \\
\text { a l i a n z a s } \\
\text { estratégicas con } \\
\text { tour operadores } \\
\text { internacionales } \\
\text { y con operadores } \\
\text { de turismo local }\end{array}$} & $\begin{array}{l}\text { - Exoneración de } \\
\text { impuestos para } \\
\text { tour operadores } \\
\text { que traigan turistas } \\
\text { internacionales a la } \\
\text { isla }\end{array}$ & $\begin{array}{l}\text { - Gobierno nacional } \\
\text { - Gobernación del Estado de } \\
\text { nueva Esparta } \\
\text { - Dirección de turismo del } \\
\text { Estado de nueva Esparta } \\
\text { - Tour operadores } \\
\text { involucradas }\end{array}$ & Dos años \\
\hline & - $\begin{array}{l}\text { Organización de } \\
\text { paquetes turísticos } \\
\text { integrales }\end{array}$ & $\begin{array}{l}\text { - } \text { Dirección de turismo del } \\
\text { Estado de Nueva Esparta } \\
\text { - Prestadores de servicios } \\
\text { turísticos } \\
\text { - Operadores turísticos } \\
\text { - Agencias de viaie }\end{array}$ & Trimestralmente \\
\hline
\end{tabular}




\begin{tabular}{|c|c|c|c|}
\hline $\begin{array}{l}\text { Planificar y } \\
\text { realizar ferias } \\
\text { turísticas } \\
\text { internacionales }\end{array}$ & $\begin{array}{l}\text { Exponer los servicios } \\
\text { turísticos, atractivos, } \\
\text { entretenimiento con } \\
\text { que cuenta la Isla }\end{array}$ & $\begin{array}{ll}\text { - } & \text { Dirección de turismo del } \\
\text { - } & \text { Estado de Nueva Esparta } \\
\text { - } & \text { Operadores turísticos } \\
\text { - } & \text { Agencias de viaje } \\
\text { Universidad de Oriente }\end{array}$ & Una vez al año \\
\hline $\begin{array}{c}\text { con el fin de dar } \\
\text { a conocer la isla } \\
\text { en los diferentes } \\
\text { mercados y } \\
\text { comercializarla } \\
\text { como } \\
\text { multidestino }\end{array}$ & \begin{tabular}{|l|} 
Invitara a los diversos \\
operadores turísticos, \\
agencias de viaje, \\
prestadores de \\
servicios turísticos \\
que operan en la isla \\
para participar en \\
dicho evento
\end{tabular} & $\begin{array}{ll}\text { - } & \text { Dirección de turismo del } \\
\text { - } & \text { Estado de Nueva Esparta } \\
\text { - } & \text { Ageradores turísticos } \\
\text { - } & \text { Universidas de viaje } \\
\end{array}$ & Una vez al año \\
\hline
\end{tabular}

\begin{tabular}{|c|c|c|c|}
\hline $\begin{array}{c}\text { Estrategia } \\
\text { FA } \\
\end{array}$ & Actividades & Responsables & Tiempos \\
\hline $\begin{array}{l}\text { Estimular a } \\
\text { los cuerpos } \\
\text { p o li c i a le s } \\
\text { para vigilar } \\
\text { y patrullar } \\
\text { los sitios } \\
\text { turísticos de } \\
\text { la isla }\end{array}$ & $\begin{array}{l}\text { - Otorgar un beneficio } \\
\text { económico para los } \\
\text { oficiales que realicen } \\
\text { guardias resguardando } \\
\text { los sitios y eventos } \\
\text { turísticos, así como los } \\
\text { turistas que asistan a } \\
\text { ellos }\end{array}$ & $\begin{array}{l}\text { - Gobernación del Estado de } \\
\text { Nueva Esparta } \\
\text { - Comandancia de la Policía } \\
\text { del Estado de Nueva } \\
\text { Esparta }\end{array}$ & Temporada alta \\
\hline $\begin{array}{l}\text { Estimular a } \\
\text { la empresa } \\
\text { Sabempe } \\
\text { (encargada } \\
\text { de recoger } \\
\text { la basura } \\
\text { en la isla) } \\
\text { para recoger } \\
\text { dos veces } \\
\text { al dia los } \\
\text { desperdicios } \\
\text { generados } \\
\text { en época de } \\
\text { temporada } \\
\text { alta }\end{array}$ & $\begin{array}{l}\text { Establecer brigadas } \\
\text { especiales de dos } \\
\text { turnos de recolectores } \\
\text { de desperdicios durante } \\
\text { las temporadas alta de } \\
\text { vacaciones }\end{array}$ & $\begin{array}{l}\text { - Gobernación del Estado de } \\
\text { Nueva Esparta } \\
\text { - Alcaldías de os municipios } \\
\text { turísticos de la isla } \\
\text { - Corporación de turismo del } \\
\text { Estado de Nueva Esparta } \\
\text { - Empresa Sabempe }\end{array}$ & Temporada Alta \\
\hline
\end{tabular}




\begin{tabular}{|c|c|c|c|}
\hline Estrategia DA & Actividades & Responsables & Tiempos \\
\hline \multirow[t]{2}{*}{$\begin{array}{l}\text { Sensibilizar y } \\
\text { capacitar a la } \\
\text { c o m u n i d a d } \\
\text { receptora para } \\
\text { el servicio } \\
\text { turístico de } \\
\text { calidad }\end{array}$} & $\begin{array}{l}\text { - Ofrecer charlas en colegios, } \\
\text { centros comunales y } \\
\text { empresas de servicio } \\
\text { turístico como hoteles, } \\
\text { restaurantes, agencias de } \\
\text { viaje, etc. con el fin de dar } \\
\text { a conocer los beneficios } \\
\text { del turismo y su aporte al } \\
\text { beneficio económico de } \\
\text { la comunidad donde se } \\
\text { desarrolla }\end{array}$ & 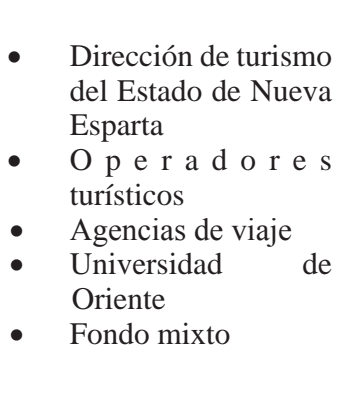 & Trimestralmente \\
\hline & $\begin{array}{l}\text { - Llevar a cabo un plan } \\
\text { de capacitación a los } \\
\text { empleados de las empresas } \\
\text { prestadoras de servicios que } \\
\text { tienen contacto directo con } \\
\text { el turista con la finalidad } \\
\text { de mejorar la calidad del } \\
\text { servicio turístico }\end{array}$ & 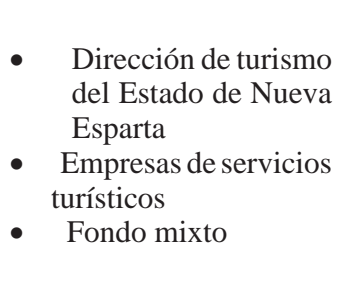 & Trimestralmente \\
\hline $\begin{array}{c}\text { Evaluar } \\
\text { periódicamente } \\
\text { la imagen } \\
\text { percibida por } \\
\text { los turistas } \\
\text { que visitan la } \\
\text { Isla Margarita } \\
\text { con el fin de } \\
\text { orientar la } \\
\text { oferta hacia la } \\
\text { demanda } \\
\end{array}$ & $\begin{array}{l}\text { - Aplicar encuestas a los } \\
\text { turistas tanto nacionales } \\
\text { como internacionales para } \\
\text { medir la imagen que se tiene } \\
\text { del destino Isla Margarita } \\
\text { y orientar la misma hacia } \\
\text { directrices planteadas }\end{array}$ & $\begin{array}{ll}\text { - } & \text { Dirección de turismo } \\
\text { del Estado de Nueva } \\
\text { Esparta } \\
\text { - } \quad \text { Fondo mixto }\end{array}$ & Una vez al año \\
\hline
\end{tabular}




\section{CONCLUSIONES}

- No existe una imagen turística consolidada del destino turístico Isla de Margarita por parte de los turistas nacionales e internacionales que la visitan.

- El perfil demográfico de los turistas nacionales está representado por Caraqueños, casados con edad promedio entre 20 y 40 años, profesionales.

- El perfil demográfico de los turistas internacionales está representado por Argentinos, masculinos con edad promedio entre 40 y 60 años, profesionales, y de estado civil: casados.

- Para el turista nacional los servicios de alojamiento restaurante transporte y agencia de viaje son buenos, a diferencia de los turistas nacionales que consideran el alojamiento y los restaurantes bueno, el transporte malo y las agencias de turismo regular.

- En cuanto a los atractivos tanto los turistas nacionales como internacionales considera bueno a las playas, parques temáticos, y centros comerciales.

- Con respecto al gusto por el destino los turistas nacionales e internacionales opinaron tenerlo alto y en cuanto a las alternativas de escoger el destino fueron muchas para ambos mercados sin embargo en cuanto al deseo de visitar el destino los nacionales manifestaron que siempre quisieron visitar la Isla de Margarita sin embargo los internacionales opinaron que alguna vez quisieron visitarla.

- Con relación a la identidad tanto para el turista nacional como internacional, la gente de la isla es muy amable, a cultura, la gastronomía y la historia muy interesante.

- El turista nacional no tuvo información turística en el lugar de origen a diferencia del internacional que si tuvo información. En el lugar de destino tanto los nacionales como internacionales no tuvieron información.

- En cuanto a la señalización los turistas internacionales no contestaron y la mitad de los nacionales opinaron que si tuvieron y la otra mitad, que no tuvieron.

- Los turistas nacionales conocieron la isla a través de familiares y amigos y los internacionales a través de Internet. 
- En cuanto a la imagen inicial de la isla los dos mercados en estudio opinaron que ha mejorado.

- La imagen en relación a la ubicación geográfica, los turistas internacionales la ven como una isla del Caribe, sin embargo los nacionales como una isla de Venezuela.

- Con relación al elemento con que relacional la Isla de Margarita, tanto el mercado nacional como internacional lo hacen con sol y la playa.

- Entre los aspectos positivos de los turistas nacionales destacan las playas a diferencia de los internacionales que destaca la amabilidad de su gente.

- Para los turistas nacionales el aspecto negativo de la isla es la basura. Para los internacionales es la basura y la poca información turística.

- La imagen de la Isla de Margarita de los turistas internacionales es diferente a la de los nacionales a pesar de poseer características que se repiten en los dos mercados estudiados.

- La Isla de Margarita posee diversidad de atractivos naturales para los turistas, establecimientos de alojamiento en buen estado, gente amable, riqueza histórica, cultural, gastronómica, parques temáticos, paisajes áridos y fríos, por lo que podría convertirse en un multidestino.

- De acuerdo a los resultados del estudio no existen argumentos contundentes como para afirmar que la Isla de Margarita es considerada un destino turístico en el Caribe de sol y playa, pero que todavía no ha alcanzado prestigio internacional ya que los turistas internacionales consideran que hay mucha basura, poca información en el destino y quejas en algunos servicios turísticos. 


\section{RECOMENDACIONES}

- Realizar estudios anuales de la imagen de la isla para conocer como se está percibiendo el destino por parte de los turistas nacionales como internacionales.

- Realizar actividades de integración para los operadores turísticos, prestadores de servicios, comunidad receptora, gobierno, con el fin de lograr una buena identificación con el desarrollo de la actividad turística en la isla.

- Realizar un plan de promoción y publicidad para los principales mercados emisores de turismo a nivel mundial con el fin de dar a conocer el destino Isla de Margarita y orientar los desplazamientos hacia este destino.

- Cuidar y mantener los atractivos turísticos con que cuenta la isla tanto naturales como artificiales.

- Estimular al personal que labora en las empresas turísticas, para ofrecer un servicio a turista personalizado y de alta calidad.

- Llevar a cabo todas las estrategias que se plantean en el análisis DOFA planteado.

Recibido: 29/05/2009

Aprobado:06/11/2009

Arbitrado anonimamente 


\section{BIBLIOGRAFÍA}

- Acerenza, Miguel Angel, (1991) Administración Del Turismo, Conceptualizacion Y Organización, Editorial Trillas Mexico.

- Baloglu, S., y Mccleary, K. W. (1999): «A Model of Destination Image Formatioll», en Annals of Tourism Research, vol. 26, núm. 4, pp. 868-897.

- Corporación de Turismo del Estado Nueva Esparta. (2008) Reporte de Estadísticas.

- Diccionario de la "Real Academia de la lengua Española.

- Estudios Turísticos (2002). El Proceso de Formación de la Imagen de los Destinos Turísticos: Una Revisión Teórica, nº 154, pp5-32

- Figuerola Palomo, M. (1995): Economía para la Gestión de las Empresas Turísticas. Editorial Centro de Estudios Ramón Areces, Colección de Estudios Turísticos. Madrid,

- Phillip, Kotler. (2000). Dirección de Mercadotecnia. México, Prentice - Hall Hispanoamericana.

- Fred, David. (1994). La gerencia estratégica. ( $9^{\mathrm{a}}$ ed.). México

- Serna, Humberto. (1994). Planeación y gestión estratégica. Colombia: Leyis.

- OMT. (1998). Introducción al Turismo, Organización Mundial del Turismo. Madrid, 1998.

- Segal Rafael Estevez "La competencia de las zonas turísticas” (Ponencia) www. travelturisme.com

- Valls, J. F. (1992): La Imagen de Marca de los Países, Madrid: McGraw-Hill.

- Valls, J. F. (1996): Las Claves del Mercado Turístico: Cómo Competir en el Nuevo Entorno, Bilbao: Deusto Turismo.

- Villafañe, Justo. (1999) Imagen corporativa. Gestión estratégica de la imagen de la empresa, Pirámide, España.

- Villafalle Justo: (2004) La Buena Reputación: Claves del Valor Intangible de las empresas, Pirámide. España. 